\title{
The Effect of Internal and External Factors on Preventive Reproductive Health Behaviors in Adolescents, in Banjarmasin, Kalimantan
}

\author{
Azura Arisa'), RB Soemanto's), Setyo Sri Rahardjo3) \\ ${ }^{1)}$ Masters Program in Public Health, Universitas Sebelas Maret \\ 2)Faculty of Social and Political Sciences, Universitas Sebelas Maret \\ 3)Faculty of Medicine, Universitas Sebelas Maret
}

\begin{abstract}
Background: Many adolescents had engaged in unhealthy sexual behavior that can result in unintended health outcomes. In theory, adolescent sexual behavior is influenced by a complex set of interactions between biology, genetics, individual perception, personality characteristics, and sociocultural norms and values. This study aimed to determine the influence of internal and external factors on preventive reproductive health behavior in adolescents, in Banjarmasin, Kalimantan, using Health Belief Model.

Subjects and Method: This was an analytic observational study with the cross sectional design. The study was conducted at 10 senior high schools in Banjarmasin, Kalimantan. A total sample of 200 grade XI students was selected for this study by proportional stratified random sampling. The dependent variable was preventive reproductive health behavior. The independent variables were perceived susceptibility, perceived seriousness, perceived threat, perceived benefit, perceived barrier, self-efficacy, the role of parents, peer role, and information access. The data were collected by questionnaire and analyzed by path analysis.

Results: The strong role of parents $(b=0.05 ; \mathrm{SE}=0.01 ; \mathrm{p}<0.001)$, perceived benefit $(\mathrm{b}=0.06$; $\mathrm{SE}=0.02 ; \mathrm{p}=0.006)$, perceived threat $(\mathrm{b}=0.10 ; \mathrm{SE}=0.02 ; \mathrm{p}<0.001)$, self-efficacy $(\mathrm{b}=0.13 ; \mathrm{SE}=$ $0.01 ; \mathrm{p}<0.001)$, and peer role $(\mathrm{b}=0.06 ; \mathrm{SE}=0.01 ; \mathrm{p}<0.001)$ positively affected preventive reproductive health behavior. Perceived barrier $(b=-0.03 ; \mathrm{SE}=0.01 ; \mathrm{p}=0.026)$ negatively affected preventive reproductive health behavior. Perceived threat increased with increasing role of parents $(b=0.05 ; \mathrm{SE}=0.02 ; \mathrm{p}=0.059)$, perceived susceptibility $(b=0.21 ; \mathrm{SE}=0.05$; $\mathrm{p}<0.001)$, perceived seriousness $(\mathrm{b}=0.10 ; \mathrm{SE}=0.04 ; \mathrm{p}=0.015)$, and self efficacy $(\mathrm{b}=0.13 ; \mathrm{SE}=$ o.06; $p=0.040)$. Perceived barrier decreased with improving access of information $(b=-0.16$; $\mathrm{SE}=0.05 ; \mathrm{p}=0.004)$. Perceived benefit increased with improving access of information $(b=0.09 ; \mathrm{SE}=0.04 ; \mathrm{p}=0.030)$ and perceived susceptibility $(\mathrm{b}=0.20 ; \mathrm{SE}=0.06 ; \mathrm{p}=0.002)$. Perceived susceptibility $(b=0.13 ; \mathrm{SE}=0.04 ; \mathrm{p}=0.004)$, perceived seriousness $(\mathrm{b}=0.10 ; \mathrm{SE}=$ $0.05 ; \mathrm{p}=0.057)$, and self efficacy $(\mathrm{b}=0.09 ; \mathrm{SE}=0.03 ; \mathrm{p}=0.006)$ increased with access of information. Self efficacy increased with stronger role of parents $(b=0.06 ; S E=0.02 ; p=0.018)$, and peer role $(b=0.07 ; \mathrm{SE}=0.04 ; \mathrm{p}=0.062)$.

Conclusion: Preventive reproductive health behavior among adolescents is affected by the role of parents, perceived of threat, self efficacy, peer role, perceived of benefit, and perceived of barrier. Health belief model can predict health preventive behavior.
\end{abstract}

Keywords: Preventive behavior, reproductive health, health belief model, internal and external factors

\section{Correspondence:}

Azura Arisa, Masters Program in Public Health, Universitas Sebelas Maret, Jl. Ir. Sutami 36A, Surakarta 57126, Central Java. Email: azura.syakura@gmail.com.

\section{BACKGROUND}

The adolescent period is known as the critical phase in life at risk for various problems, includes free sex. Based on WHO (2015), which reported an increase in delivery cases among adolescent girls 
Journal of Health Promotion and Behavior (2017), 2(4): 350-358

https://doi.org/10.26911/thejhpb.2017.02.04.07

aged 15-19 years to 49 births per 1000 with $11 \%$ experienced complications in pregnancy and childbirth. As many as 4.4 million adolescents in developing countries have abortions. BKKBN (2012) noted cases of teenage pregnancy out of marriage as many as $48.1 \%$ and 800,000 teenagers have an abortion.

Based on Indonesian Basic Health Survey (2012) reported that there are 220 cases of pregnant teenagers out of marriage, 325 adolescents girls give birth, and 30 cases of adolescents having reproductive tract infections, in Banjarmasin, Kalimantan (BKKBN Provinsi Kalimantan Selatan, 2013)

Sexual activities conducted by adolescents have a negative impact on themselves, family, and social environment, so the need for preventive behavior as a protection for the future life of adolescents (WHO cit Mmari et al., 2013).

Sulaeman (2016) stated that behavior is formed based on internal and external factors. Mmari et al. (2013) mentioned the protective factor against sexual risk behavior in adolescents not only focusing on the individual itself, but the need for the involvement of others and the environment such as government, the role of family, peers, and access to information.

Efforts to strengthen adolescent reproductive health prevention behavior theoretically can be explained through Health Belief Model Theory (HBM) by Hochbaum, Rosenstock, and Kegels (Sulaeman, 2016). This model explains health preventive behavior influenced by internal factors such as perceived of susceptibility, perceived seriousness, perceived benefits, perceived barriers, and self-efficacy. External factors (cues of action) such as access to information, parent roles, and peer support.
Based on the above explanation, the success of efforts to strengthen preventive behavior of adolescent reproductive health is needed by the involvement of guidance and support from all parties. This stud aimed to analyze the influence of internal and external factors on preventive behavior of reproductive health in adolescent, in Banjarmasin, Kalimantan, using Health Belief Model.

\section{SUBJECTS AND METHOD \\ 1. Study design}

This was an analytic and observational study with a cross sectional design. The study was conducted at 10 senior high schools in Banjarmasin, Kalimantan, Indonesia, in November 2017.

\section{Population and Sample}

A total sample of 200 grade XI students was selected for this study by proportional stratified random sampling.

\section{Variable of the study}

The dependent variable was preventive reproductive health behavior. The independent variables were perceived susceptibility, perceived seriousness, perceived threat, perceived benefit, perceived barrier, self-efficacy, the role of parents, peer role, and information access.

\section{Operasional definition of variable}

Perceived susceptibility was defined as an understanding of adolescent about vulnerability condition of reproductive organ exposed to sexual disease caused by viruses, bacteria, and fungi. The data was measured by questionnaire. The measurement scale was continuous.

Perceived seriousness was defined as the understanding of adolescents on the severity/seriousness of seeking health reproduction in terms of prevention of sexual transmitter transmission.

Perceived threat was defined as adolescent consciousness about reproductive health threats including premarital 
sexual behavior impact and sexual disease transmission. The measurement scale was continuous.

Perceived benefit was defined as the adolescent's understanding of the benefits of maintaining reproductive health in the prevention of sexual disease transmission. The measurement scale was continuous.

Perceived barrier was defined as the adolescent's understanding of the barriers when maintaining reproductive health in the prevention of sexual disease transmission. The measurement scale was continuous.

Self-efficacy was defined as the ability of adolescents in maintaining reproductive health and avoiding promiscuity to prevent transmission of sexual diseases. The measurement scale was continuous.

Parent role was defined as parent involvement (father and mother) in communicating with adolescents includes supervision, attention, and advice on reproductive health information. The measurement scale was continuous.

Peer support was defined as the positive influence of peers in maintaining adolescent reproductive health and preventing the transmission of sexual diseases. The measurement scale was continuous.

Information access was defined as the availability of information obtained by adolescents on reproductive health through printed media, electronic media, or health workers. The measurement scale was continuous.

\section{Study instrument}

The data of preventive behaviour of reproductive health was measured by Lie Minnesota Multiphasic Personality (L-
MMPI) scale. The other data was collected by questionnaire.

\section{Data analysis}

The categorical data of the study subject's characteristic were described in frequency (n) and percentage (\%). Univariate analysis was described in mean, standard deviation (SD), minimum and maximum value. Bivariate analysis was analyzed by Pearson correlation test.

Multivariate analysis was analyzed using path analysis by IBM SPSS AMOS 22 version, following steps:

a. Model specification

b. Model identification

c. Model fit

d. Parameter estimation

e. Model re-specification

\section{Research ethics approval}

The research ethics clearance for this study was obtained from the Research Committee at Dr. Moewardi Hospital. Research ethics included informed consent, anonymity, and confidentiality.

\section{\begin{tabular}{|c}
\hline \multicolumn{2}{c}{ RESULTS } \\
\hline 1. Characteristic of the study
\end{tabular} subjects}

Table 1 showed that most of the study subjects were female (104 students, $52.0 \%$ ), class of natural sciences (101 students, 50.0\%), and Muslims (113 students, $56.5 \%)$.

\section{Bivariate analysis}

The bivariate analysis on the Table 2 showed that perceived susceptibility, perceived seriousness, perceived threat, perceived benefit, self-efficacy, parental role, and information access were positively affected with preventive behaviour of reproduction health. Perceived barrier was negatively affected with preventive reproduction health behavior. 
Table 1. Characteristic of the study subjects

\begin{tabular}{clrc}
\hline No. & \multicolumn{1}{c}{ Characteristics } & N & \% \\
\hline 1. & Age & 64 & \\
& 16 years & 78 & 32.0 \\
& 17 years & 58 & 39.0 \\
18 years & & 29.0 \\
2ex & 96 & 48.0 \\
& Male & 104 & 52.0 \\
Female & & \\
3. Study major & 101 & 50.5 \\
& Natural sciences & 99 & 49.5 \\
Social sciences & & \\
Religion & 113 & 56.5 \\
& Muslim & 30 & 15.0 \\
& Catholic/ Christian & 29 & 14.5 \\
& Christian Protestant & 28 & 14.0 \\
Budha & & \\
5. Parental education & 16 & 8.0 \\
& Elementary school & 49 & 24.5 \\
& Junior high school & 88 & 44.0 \\
\hline
\end{tabular}

Table 2. The results of bivariate analysis

\begin{tabular}{lcc}
\hline \multicolumn{1}{c}{ Independent variable } & $\mathbf{r}$ & $\mathbf{p}$ \\
\hline Perceived susceptibility & 0.14 & 0.045 \\
Perceived seriousness & 0.18 & 0.010 \\
Perceived threat & 0.32 & $<0.001$ \\
Perceived benefit & 0.20 & 0.003 \\
Perceived barrier & -0.13 & 0.055 \\
Self efficacy & 0.39 & $<0.001$ \\
Parental role & 0.39 & $<0.001$ \\
Peer role & 0.35 & $<0.001$ \\
Information access & 0.26 & $<0.001$ \\
\hline
\end{tabular}

\section{Path Analysis}

\section{a. Model specification}

Table 3 showed that preventive behaviour of reproductive health increased with parental role $(b=0.05, \mathrm{SE}=0.01, \mathrm{p}$ $<0.001)$, perceived benefit $(\mathrm{b}=0.06, \mathrm{SE}=$ $0.02, \mathrm{p}=0.006)$, perceived threat $(\mathrm{b}=$ $0.02, \mathrm{SE}=0.02, \mathrm{p}<0.001)$, self-efficacy $(b=0.13, \mathrm{SE}=0.02, \mathrm{p}<0.001)$, and peer role $(\mathrm{b}=0.06, \mathrm{SE}=0.01, \mathrm{p}<0.001)$. Preventive reproductive health behavior decreased with perceived barrier $(b=-$ $0.03, \mathrm{SE}=0.01, \mathrm{p}=0.026$ ).

Perceived threat increased with selfefficacy $(b=0.13, \mathrm{SE}=0.06, \mathrm{p}=0.040)$, perceived susceptibility $(b=0.21, \mathrm{SE}=$ $0.05, \mathrm{p}<0.001)$, perceived seriousness $(\mathrm{b}=$
0.10, $\mathrm{SE}=0.04, \mathrm{p}=0.015)$, and parental role $(b=0.05, \mathrm{SE}=0.02, \mathrm{p}=0.059)$,

Perceived threat decreased with higher information access $(b=0.16, \mathrm{SE}=$ 0.05, $\mathrm{p}=0.004$ ).

Perceived benefit increased with perceived benefit $(b=0.20, S E=0.06, p=$ 0.002), higher information access $(b=$ 0.09, $\mathrm{SE}=0.04, \mathrm{p}=0.030$ ).

Perceived susceptibility $(b=0.13$, $\mathrm{SE}=0.04, \mathrm{p}=0.004)$ and perceived seriousness $(b=0.10, \mathrm{SE}=0.05, \mathrm{p}=0.057)$ increased with higher information access.

Self-efficacy increased with higher information access $(b=0.09, \mathrm{SE}=0.03$, $\mathrm{p}=0.006)$, stronger parental role $(\mathrm{b}=$ $0.06, \mathrm{SE}=0.02, \mathrm{p}=0.018$ ), and peer role $(b=0.07, S E=0.04, p=0.062)$. 


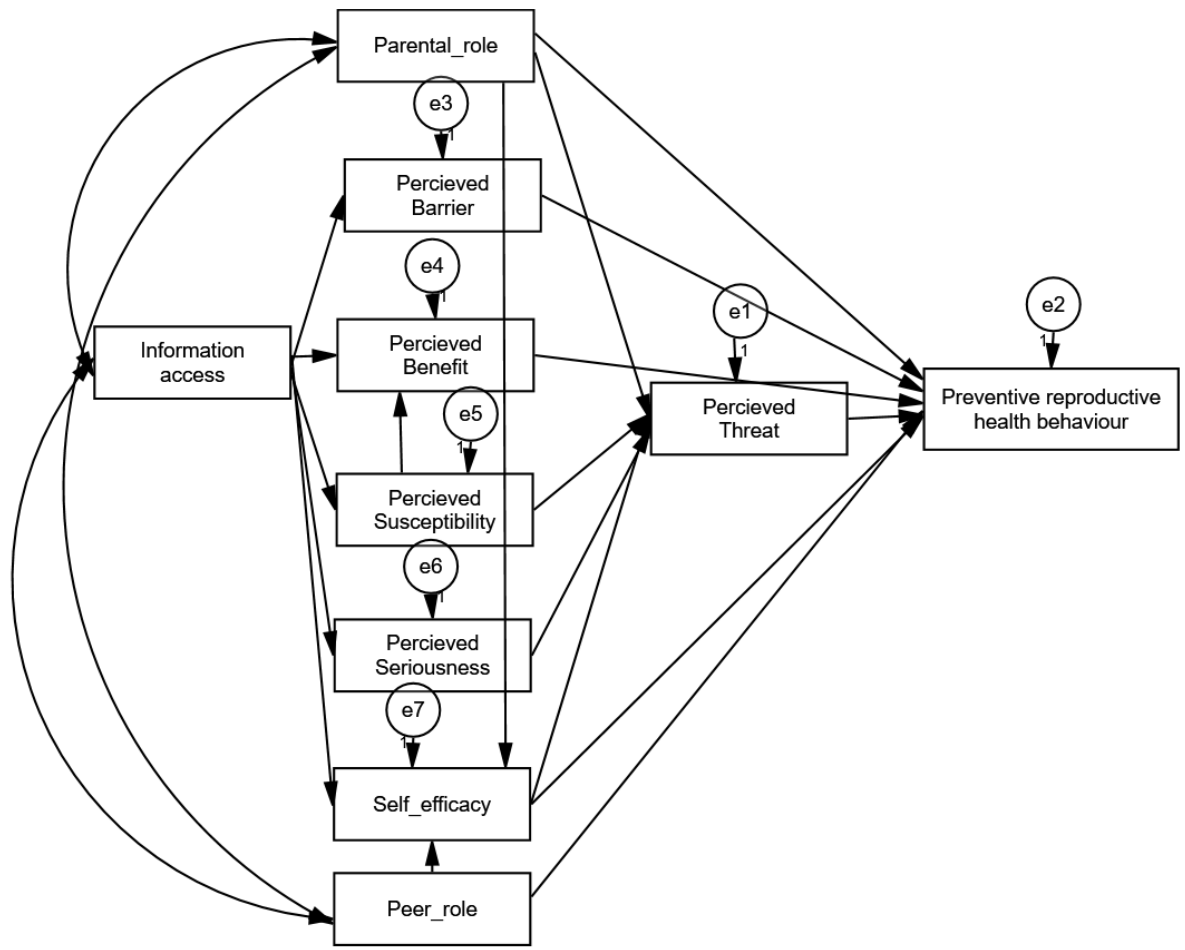

Figure 1 Model fit and parameter estimation

Table 3. Path analysis on the effect of the influence of internal and external factors on preventive reproductive health behavior in adolescents

\begin{tabular}{|c|c|c|c|c|c|c|}
\hline \multirow{2}{*}{\multicolumn{2}{|c|}{$\begin{array}{c}\text { Dependent variable } \\
\text { Direct effect }\end{array}$}} & Independent variable & \multirow[t]{2}{*}{$\mathbf{b}^{*}$} & \multirow[t]{2}{*}{ SE } & \multirow[t]{2}{*}{$\mathbf{p}$} & \multirow[t]{2}{*}{$\boldsymbol{\beta}^{* *}$} \\
\hline & & & & & & \\
\hline $\begin{array}{l}\text { Preventive reproductive health } \\
\text { behaviour }\end{array}$ & $\leftarrow$ & The role of parents & 0.05 & 0.01 & $<0.001$ & $4 \cdot 37$ \\
\hline $\begin{array}{l}\text { Preventive reproductive health } \\
\text { behaviour }\end{array}$ & $\leftarrow$ & Perceived barrier & -0.03 & 0.01 & 0.026 & -2.23 \\
\hline $\begin{array}{l}\text { Preventive reproductive health } \\
\text { behaviour }\end{array}$ & $\leftarrow$ & Perceived benefit & 0.06 & 0.02 & 0.006 & 2.75 \\
\hline $\begin{array}{l}\text { Preventive reproductive health } \\
\text { behaviour }\end{array}$ & $\leftarrow$ & Perceived threat & 0.10 & 0.02 & $<0.001$ & 3.54 \\
\hline $\begin{array}{l}\text { Preventive reproductive health } \\
\text { behaviour }\end{array}$ & $\leftarrow$ & Self efficacy & 0.13 & 0.02 & $<0.001$ & 4.60 \\
\hline $\begin{array}{l}\text { Preventive reproductive health } \\
\text { behaviour }\end{array}$ & $\leftarrow$ & Peer role & 0.06 & 0.01 & $<0.001$ & 3.76 \\
\hline \multicolumn{7}{|l|}{ Indirect effect } \\
\hline Perceived threat & $\leftarrow$ & Parental role & 0.05 & 0.02 & 0.059 & 1.88 \\
\hline Perceived threat & $\leftarrow$ & Perceived susceptibility & 0.21 & 0.05 & $<0.001$ & 4.19 \\
\hline Perceived threat & $\leftarrow$ & Perceived seriousness & 0.10 & 0.04 & 0.015 & 2.42 \\
\hline Perceived threat & $\leftarrow$ & Self efficacy & 0.13 & 0.06 & 0.040 & 2.05 \\
\hline Perceived barrier & $\leftarrow$ & Access of information & -0.16 & 0.05 & 0.004 & -2.87 \\
\hline Perceived benefit & $\leftarrow$ & Access of information & 0.09 & 0.04 & 0.030 & 2.16 \\
\hline Perceived benefit & $\leftarrow$ & Perceived susceptibility & 0.20 & 0.06 & 0.002 & 3.17 \\
\hline Perceived susceptibility & $\leftarrow$ & Access of information & 0.13 & 0.04 & 0.004 & 2.84 \\
\hline Perceived seriousness & $\leftarrow$ & Access of information & 0.10 & 0.05 & 0.057 & 1.90 \\
\hline Self efficacy & $\leftarrow$ & Access of information & 0.09 & 0.03 & 0.006 & 2.72 \\
\hline Self efficacy & $\leftarrow$ & Parental role & 0.06 & 0.02 & 0.018 & 2.36 \\
\hline Self efficacy & $\leftarrow$ & Peer role & 0.07 & 0.04 & 0.062 & 1.86 \\
\hline \multirow{2}{*}{\multicolumn{7}{|c|}{$\mathrm{N}$ observation $=200$}} \\
\hline Model Fit: & & & & & & \\
\hline \multirow{2}{*}{\multicolumn{2}{|c|}{$\begin{array}{l}\text { CMIN }=41.29 \quad p=0.015(\geq 0.05) \\
\text { RMSEA }=0.06(<0.08)\end{array}$}} & $\mathrm{GFI}=0.96 \mathrm{NFI}=0.83 \mathrm{CF}$ & $=0.91$ & & & \\
\hline & & $\beta^{* *}=$ Standarized path c & efficient & & & \\
\hline
\end{tabular}


Journal of Health Promotion and Behavior (2017), 2(4): 350-358

https://doi.org/10.26911/thejhpb.2017.02.04.07

\section{DISCUSSION}

1. The association between parental role and preventive reproductive health behavior in adolescents

This study showed that parental role was directly associated with preventive behaviour of reproductive health. Parental role was indirectly associated with preventive behaviour of reproductive health through self-efficacy and perceived threat.

The role of parents is very important in the life of adolescents, namely educating, directing, supervising the behavior of everyday teenagers (Parke and Buriel cit Santrock, 2007). In the stage of adolescent development required the communication process and supervision of parents to the behavior of adolescent reproductive health (BKKBN, 2013)

Sidze and Defo (2013) reported that the higher the quality of adolescent communication with parents the less likely the adolescents having sex with their peers. Parental exposition of perceived threat including the social value, culture, and norm, is a guide for adolescents to control sexual behavior (Bleakley et al., 2011 in Harris, 2016). Markazi and Badrigargari (2011) showed that parental role and parenting pattern were associated with self-efficacy in girl adolescent.

2. The association between perceived barrier and preventive reproductive health behavior in adolescents

The results of path analysis showed that perceived barrier was negatively associated with preventive reproductive health behavior in adolescents. Perceived barrier refers to an individual's assessment of the perceived barriers to behavior change (Janz and Backer 1984 in Sulaeman, 2016). Adolescents who are able to overcome obstacles and barriers to healthy behavior have good preventative health reproductive behavior.

This finding is consistent with Marmarà et al. (2017) that construction of health belief theory indicates woman aged 50-60 years do not want to do breast examination for fear of cancer diagnosed.

3. The association between perceived benefit and preventive reproductive health behavior in adolescents

This study showed that perceived benefit was associated with preventive reproductive health behavior. Another construct of the health belief model is the perceived benefit of healthy behavior. Perceived benefit refers to the individual assessment of efficacy to reduce the risk of disease (Resenstock 1974 in Sulaeman, 2016).

Teenagers with high confidence in the future benefit of preventive behavior will try to do activities that maintain reproductive health, for example, clean healthy life, clean genital hygiene, and avoidance of promiscuous sexual behavior. Didarloo et al. (2017) also stated that early breast examination in girl adolescent provides benefits in breast cancer detection.

\section{The association betweeen per- ceived threat and preventive reproductive health behavior in adolescents}

The results of path analysis showed that perceived threat positively associated with preventive reproductive health behavior.

Perceived threat focus on the individual's perception of vulnerability and the seriousness or severity of a disease. If adolescents feel threatened against the risk of reproductive diseases, then adolescents will perform preventive behaviors against reproductive infection. Assessment of perceived threats is based on the 
circumstances that enable a person to transmit the disease.

Noegroho et al., (2015) stated that preventive behaviour of reproductive health in adolescent increased with perceived threat.

\section{The association between self effi- cacy and preventive reproductive health behavior in adolescents}

The result of path analysis showed that self-efficacy was directly associated with preventive reproduction health behaviour in adolescents. In addition, self-efficacy showed an indirect positive effect through the perceived threat on preventive reproductive health behavior.

Self-efficacy is a self-confidence of an individual's ability to well perform a certain action so that he tried to show the best thing he could do in order to achieve the maximum result (Bandura, 1977 in Sulaeman, 2016). Self-efficacy plays an important role in the daily life of adolescents, in this case, the preventive reproductive health behavior.

Another study by Wheeler's (2010) found that high self-efficacy in adolescent girls was correlated with decision making for non-sexual intercourse. In the health belief model, the high perception of health threat will increase the self-efficacy of adolescents, in this case, adolescents being able to manage the aspects of his efficacy.

\section{The association between peer role and preventive of reproductive health behavior in adolescents}

The results of path analysis showed that peer role was directly and positively associated with preventive reproductive health behavior in adolescents. Peer role was associated with preventive behavior of reproductive health through self efficacy.

Peers are a group of people of approximately the same age as themselves (Santrock, 2007). According to Stanhope and Lancaster (2004) in Yusuf (2014) peers have an important role in the development of personality and identity. Cattelino et al. (2014) explained that associating with good moral friends can reduce the influence of deviant behavior in adolescents. The good association provides a positive effect on health by avoiding sexual behavior in adolescents.

The potential development process of adolescents required high self-efficacy and supported the role of peers. The results showed the relationship between peer social support and self-efficacy of adolescents. Adolescents with high peer support have a high efficacy for health status (Thompson et al., 2016).

7. The association between perceived susceptibility with preventive reproductive health behavior in adolescents

Path analysis results showed that there was an indirect positive influence of perceived vulnerability on reproductive health preventive behavior through assessment of health threat and perceived benefit.

Perceived susceptibility is a part of the theoretical health belief model. Resenstock (1974) in Sulaeman (2016) explains that a person with a high susceptibility perception believes that he or she is at high risk for disease if it is unhealthy.

\section{The association between per- ceived seriousness and preventive reproductive health behavior in adolescents}

The results of path analysis showed that perceived seriousness was positively associated with preventive behaviour of reproductive health through perceived of threat.

Perceived seriousness were a form of assessment of the severity of health problems and its potential consequences 
(Janz et al., 1984; Glanz cit Sulaeman, 2016). Didarloo et al., (2017) stated that perceptions of high disease severity affect the awareness of adolescent girls to perform breast self-examination.

\section{The association between infor- mation access and preventive reproductive health behavior in adolescents}

The results of path analysis showed that information access was associated with preventive reproduction health behaviour through perceived susceptibility, perceived seriousness, perceived benefit, and self-efficacy. Access of health service was associated with preventive reproductive health behaviour through perceived barrier.

Katz et al., in Ruben (2013) stated that adolescents' needs for reproductive health information can be met by accessing the media. Chàvez et al., (2013) stated that the use of digital technology positively associated with the prevention of sexually transmitted disease and HIV in the adolescent.

This study concludes that internal and external factors are associated with preventive behaviour of reproductive. This finding is consistent with health belief model on predicting preventive health behavior.

\section{REFERENCE}

BKKBN (2012). Survei Demografi dan

Kesehatan Indonesia 2012: Kesehatan Reproduksi Remaja. Jakarta: (2013). Remaja Genre dan Perkawinan Dini. Jakarta: Direktorat Remaja dan Perlindungan Hak-hak Reproduksi.

BKKBN Provinsi Kalimantan Selatan (2013). Perilaku Seksual Remaja di Kota Banjarmasin. Diakses pada tanggal 20052017 online dengan http://kalsel.bkkbn.go.id/.
Chàvez NR, Shearer LS, Rosenthal SL (2013). Use of Digital Media Technology for Primary Prevention of STIs/HIV in Youth. North American Society for Pediatric and Adolescent Gynecology. http://dx.doi.org/10.1016/j.jpag.2013.07.008.

Cattelino E, Glowacz F, Born M, Testa S, Bina M, Calandri E (2014). Adolescent Risk Behaviours and Protective Factors Against Peer in Fl Uence. Journal of Adolescence. 37(8): 1353-1362. doi: 10.1016/j.adolescence.2014.09.013.

Didarloo A, Nabilou B, Khalkhali HR (2017). Psychosocial Predictors of Breast Self- Examination Behavior among Female Students: An Application of the Health Belief Model Using Logistic Regression. BMC Public Health, 1-8. doi: 10.1186/s12889-017-4880-9.

Harris A (2016). Parent-Adolescent Sexual Communication. Nursing for Women's Health, 2O(2): 211-217. doi: 10.1016/j.nwh.2016.01.002.

Markazi L, Badrigargari R (2011). Social and the Role of Parenting Self-Efficacy and Parenting Styles on SelfRegulation Learning in Adolescent Girls of Tabriz. BMC Public Health, 1758-176o. doi: 10.1016/j.sbspro.2011.10.339.

Marmarà D, Marmarà V, Hubbard G (2017). Health Beliefs, Illness Perceptions and Determinants of Breast Screening Uptake in Malta: A CrossSectional Survey. BMC Public Health, 1-19. doi: 10.1186/s12889017-4324-6.

Mmari K, Sabherwal S (2013). Review article a Review of Risk and Protective Factors for Adolescent Sexual and Reproductive Health in Developing Countries: An Update. Journal of Adolescent Health, 53(5): 
562-572. doi: 10.1016/j.jadohealth.2013.07.018.

Noegroho A, Hariadi SS, Priatamtama PW (2015). Faktor-faktor Pengaruhi Perilaku Kesehatan Reproduksi Remaja Kabupaten Bannyumas. Kawistara, 5(1): 1-98.

Radar Banjarmasain (2016). Kisah Lengkap: Aksi Mesum di HalamanMasjid Raya Sabilal Muhtadin Banjarmasin Kalsel. Di akses pada tanggal 2005 2017 online dengan http://kalsel.prokal.co/read/news/1407-kisahlengkap-aksi-mesum-di-halamanmasjid-raya-sabilal-muhtadinbanjarmasin-kalsel.html.

Ruben (2013). Communication and $\mathrm{Hu}-$ man Behaviour. 5th Edition. Jakarta: Rajawali Pers.

Sidze EM, Defo BK (2013). Effects of Parenting Practices on Sexual RiskTaking among Young People in
Cameroom. BMC Public Health, 13: 616.

Thompson HM, Stevenson A, Cooley ME. (2016). Children and Youth Services Review Self-esteem: A Mediator Between Peer Relationships and Behaviors of Adolescents In Foster Care. Children and Youth Services Review, 66: 109-116. doi: 10.1016/j.childyouth.2016.05.003.

Wheeler SB (2010). Effects of Self-Esteem and Academic Performance on Adolescent Decision-Making: An Examination of Early Sexual Intercourse and Illegal Substance Use. Journal of Adolescent Health, 47(6): 582590. doi:10.1016/j.jadohealth.2010.04.009.

Word Health Organization. (2015). Global Health Observatory (GHO) Data: Adolescent Birth Rate. 